\title{
How to be a self-fertile hermaphrodite
}

\author{
P.H. GOUYON
}

C.E.P.E. L, Emberger, B.P. 5051, F 34033 Montpellier Cedex and 1.N.A. Paris, Grignon, F 75231 Paris Cedex 05

\section{Summary}

The model of Charnov et al. (1976) on sex investments in hermaphrodites is modified to include self-fertilization. The modified model here shows that selfing in hermaphroditic organisms should increase maternal investment. However, in gynodioecious species, the degree of maternal investment should be affected by the amount of heterosis in the population.

Key-words : Sex allocation, game theory, selfing, gynodioecy.

\section{Résumé}

\section{Comment être un hermaphrodite auto-compatible}

Le modèle de Charnov et al. (1976) sur les investissements reproductifs chez les hermaphrodites est modifié par l'introduction de l'autofécondation. Les résultats montrent que l'autofécondation devrait augmenter l'investissement dans la fonction femelle chez les espèces hermaphrodites. Cependant, chez les espèces gynodioïques, l'investissement femelle doit être augmenté ou diminué selon l'intensité de l'hétérosis dans la population.

Mots-clés : Allocation au sexe, théorie des jeux, autofécondation, gynodioécie.

\section{Introduction}

In a purely hermaphroditic population, the investments of hermaphrodites in the male and female functions are approximately equivalent according to the model of Charnov, Maynard-Smith \& Bull (1976). Gynodioecious populations are composed of female individuals and hermaphrodite individuals. Hermaphrodites in gynodioecious populations are predicted to have a greater investment in paternal investment and therefore a decrease in maternal investment. This can be easily explained by competition among hermaphrodites for the pollination of females. Their model, using the game theory, is an alternative to the classical interpretation of the evolution of sex : it does 
not take into account the effect of sexual strategies on the breeding structure of populations. It is necessary to incorporate both aspects of the problem.

For that reason, the aim of the present paper is to answer the question «How would the introduction of selfing and inbreeding depression modify the model of Charnov et al. (op. cit.) ?». The case of populations composed of only hermaphrodites was studied by D. Charlesworth \& B. Charlesworth (1981). They discussed the different possible assumptions which can be made about the selfing rate. We studied here, both cases (hermaphroditic populations with and without females) and chose the simplest possible hypothesis concerning the selfing rate.

\section{The model}

The parametres used here are the same as those in Charnov et al. (op. cit) :

$\alpha=$ Number of pollen grains produced by a hermaphrodite $(\alpha \mathrm{N}) /$ number of pollen grains produced by a male $(\mathrm{N})$,

$\beta=$ Number of ovules produced by a hermaphrodite $(\beta n) /$ number of ovules produced by a female (n),

$h, m$ and $f$ are the respective proportions of hermaphrodites, males and females in the population at the time of reproduction.

In addition, the following parametres will be introduced :

$\mathrm{s}=$ proportion of selfed ovules in a hermaphrodite,

$\mathrm{d}=$ inbreeding depression $=$ probability of survival of a selfed seed/probability of survival of an outcrossed seed,

$\mathbf{t}=$ coefficient of male gametes waste in selfing (a hermaphrodite uses st male gametes to self $\mathrm{s}$ ovules).

The relationships between $\alpha$ and $\beta$ are the same as those used by CHaRnov et al. and the area containing the possibilities for these two parametres is likewise called the « fitness set $»$.

\section{A. In the absence of male and female individuals in the population}

The fitness of a hermaphroditic organism with a strategy $(\alpha, \beta, s)$ in a population with a strategy $\left(\alpha^{*}, \beta^{*}, s^{*}\right)$ is (tabl. 1):

$$
\mathrm{w}=\frac{\beta}{\beta^{*}} \frac{2 \mathrm{sd}+1-\mathrm{s}}{\mathrm{s}^{*} \mathrm{~d}+1-\mathrm{s}^{*}}+\frac{\alpha}{\alpha^{*}} \frac{1-\mathrm{s}^{*}}{\mathrm{~s}^{*} \mathrm{~d}+1-\mathrm{s}^{*}} \frac{1-\mathrm{st}}{1-\mathrm{s}^{* t}}
$$

For a given value of $s, s=s^{*}$, this formula becomes :

$$
\begin{gathered}
\mathrm{w}=\frac{\beta}{\beta^{*}} \frac{2 \mathrm{sd}+1-\mathrm{s}}{\mathrm{sd}+1-\mathrm{s}}+\frac{\alpha}{\alpha^{*}} \frac{1-\mathrm{s}}{\mathrm{sd}+1-\mathrm{s}} \\
\text { Let } \mathrm{k}=\frac{1-\mathrm{s}}{1-\mathrm{s}+2 \mathrm{sd}}, 0<\mathrm{k}<1,
\end{gathered}
$$




\section{TABLE 1}

Fitness of an individual of strategy $(\alpha, \beta)$ in a population of strategy $\left(\alpha^{*}, \beta^{*}\right)$.

Valeur sélective d'un individu de stratégie $(\alpha, \beta)$ dans une population de stratégie ( $\left.\alpha^{*}, \beta^{*}\right)$.

\begin{tabular}{|c|c|c|c|}
\hline \multirow{2}{*}{$\begin{array}{c}\text { Genes } \\
\text { transmitted } \\
\text { by }\end{array}$} & \multicolumn{3}{|c|}{ Fertilization } \\
\hline & Self & \multicolumn{2}{|r|}{ Cross } \\
\hline Pollen ..... & Nast & \multicolumn{2}{|r|}{$\mathrm{N} \alpha(1-\mathrm{st})$} \\
\hline Ovules & $\mathrm{n} \beta \mathrm{s}$ & \multicolumn{2}{|r|}{$\mathrm{n} \beta(1-\mathrm{s})$} \\
\hline \multirow[t]{2}{*}{$\begin{array}{l}\text { Genes } \\
\text { in seeds }\end{array}$} & \multirow[t]{2}{*}{$\begin{array}{l}\text { Genes from both } \\
\text { ovules and pollen } \\
2 \mathrm{~s} \beta \mathrm{n}\end{array}$} & \multirow[t]{2}{*}{$\begin{array}{c}\text { Genes from } \\
\text { ovules } \\
(1-s) \beta n\end{array}$} & $\begin{array}{l}\text { Genes from pollen } \\
\begin{array}{c}\mathbf{K}\left(1-\mathrm{s}^{*}\right) \beta^{*} \mathrm{n} \\
\text { available } \\
\text { ovules } \\
\alpha \mathrm{N}(1-\mathrm{st})\end{array}\end{array}$ \\
\hline & & & $\alpha^{*} \mathrm{~N}\left(1-\mathrm{s}^{*} \mathrm{t}\right) \mathrm{K}$ \\
\hline $\begin{array}{l}\text { Genes } \\
\text { in adults }\end{array}$ & $2 \mathrm{sd} \beta \mathrm{n}$ & $(1-s) \beta n$ & $\left(1-\mathrm{s}^{*}\right) \beta^{*} \mathrm{n} \frac{\alpha}{\alpha^{*}} \frac{1-\mathrm{st}}{1-\mathrm{s}^{*} \mathrm{t}}$ \\
\hline
\end{tabular}

$\mathrm{K}=$ Total number of individuals.

With $\overline{\mathrm{W}}=\mathrm{n} \beta^{*}\left(\mathrm{~s}^{*} \mathrm{~d}+1-\mathrm{s}^{*}\right)$

$$
w=\frac{\beta}{\beta^{*}} \frac{2 s d+1-s}{s^{*} d+1-s^{*}}+\frac{\alpha}{\alpha^{*}} \frac{1-s^{*}}{s^{*} d+1-s^{*}} \frac{1-s^{*}}{1-s^{*} t}
$$

w is proportionnal to $\alpha^{*} \beta+\alpha \beta^{*} k$. The ESS (Evolutionnary Stable Strategy), defined as a set of values of $\alpha^{*}$ and $\beta^{*}$ such that no mutant with a different strategy can be selected, is obtained when the maximum value of $w$ is for $\alpha=\alpha^{*}$ and $\beta=\beta^{*}$. That is, when :

$k \log \left(\alpha^{*}\right)+\log \left(\beta^{*}\right)$ is at a maximum $\Leftrightarrow \beta^{*} \alpha^{*} k$ is at a maximum. This result is the same as the one obtained by ChaRnov (1982, p. 230). This condition corresponds graphically to the tangent between the fitness set and a hyperbola (fig. 1).

The parametre $k$ is equal to 1 when $s=0$ or $d=0$ (i.e. there is no viable selfed zygote). In that case, the result is the same as in Charnov et al. (1976). When sd $\neq 0$ (i.e. selfing occurs and results in viable individuals), $k$ is less than 1 and the ESS occurs at highers values of $\beta$ (and decreased values of $\alpha$ ). This result could be predicted without calculation for two reasons.

- First, a selfed egg contains twice as many genes from its mother than an outcrossed one does. 

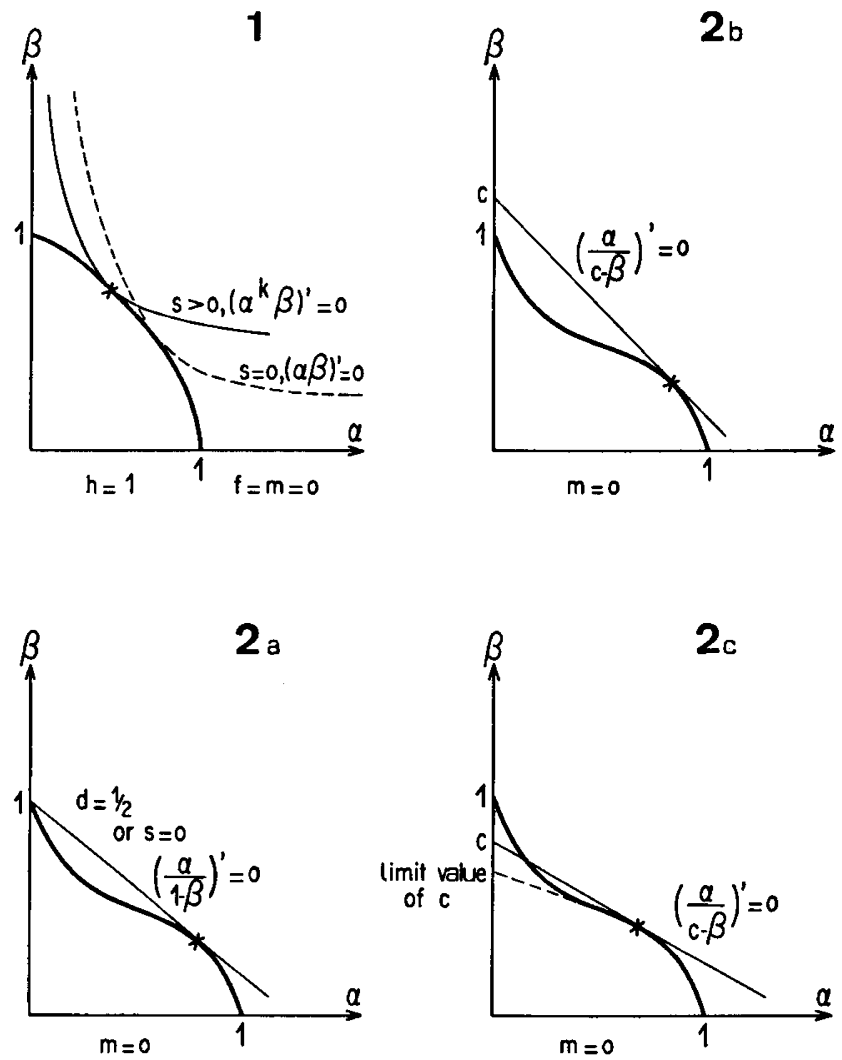

FIG. 1

In a population with hermaphrodites and without any male or female individual, the ESS is given by the tangent between the fitness set and the hyperbola $\beta=M / \alpha^{k}$ $(M=$ maximum possible value).

Dans une population composée d'hermaphrodites sans femelles ni mâles, l'ESS est donnée par la tangente entre le "fitness set» et l'hyperbole de formule $\beta=M / \alpha^{k}$ $(M=$ valeur maximale possible $)$.

FIG. 2

In a gynodioecious population (hermaphrodites with females and without males), the ESS is given by the tangent between the fitness set and the line $\beta=-M \alpha+c$ ( $M=$ maximum possible value)

Dans une population gynodiöque (hermaphrodites et femelles sans mâles), l'ESS est donné par la tangente entre le «fitness set » et la droite $\beta=-M \alpha+c$ $(M=$ valeur maximale possible $)$

a) with medium heterosis.

en condition d'hétérosis moyen.

b) with strong heterosis.

en condition de fort hétérosis.

c) with low heterosis.

en condition de faible hétérosis. 
- Second, since all other ovules in the population are selfed, there is no use in trying to fertilise them. These results are in agreement with those from D. CharlesWORTH \& B. Charlesworth (1981).

Charnov et al. (1976) demonstrated that the presence of females caused an increase of $\alpha$ in the hermaphrodites; we have seen that selfing increased the value of $\beta$. What is the effect of these two factors together?

\section{B. In the presence of female and hermaphrodite individuals (gynodioecy)}

Table 2 shows, in a population $\left(\alpha^{*}, \beta^{*}, s^{*}\right)$, the following fitness for a hermaphrodite $(\mathrm{a}, \beta, \mathrm{s})$ :

$$
\begin{gathered}
\text { Wh }=\frac{\beta(1-s+2 s d)}{f+h \beta^{*}\left(1-s^{*}+s^{* d}\right)} \\
+\frac{\alpha}{\alpha^{*}} \frac{1-s t}{1-s^{* t}} \frac{f+h \beta^{*}\left(1-s^{*}\right)}{h f+h^{2} \beta^{*}\left(1-s^{*}+s^{*} d\right)}
\end{gathered}
$$

and for a female,$$
\mathrm{Wf}=\frac{1}{\mathrm{f}+\mathrm{h} \beta^{*}\left(1-\mathrm{s}^{*}+\mathrm{s}^{*} \mathrm{~d}\right)}
$$

The equilibrium must be such that $s=s^{*}, \alpha=\alpha^{*}, \beta=\beta^{*}$ and $\mathrm{Wh}=\mathrm{Wf}$. Females are then maintained in the population only if $2 \beta<1 /(1-\mathrm{s}+\mathrm{sd})$ and, if so, $\mathbf{f}=\mathbf{h}(1-2 \beta(1-\mathrm{s}+\mathrm{sd}))$.

If $s$ is fixed $\left(s=s^{*}\right)$, the hermaphrodite's fitness is proportionnal to

$w=\beta \alpha^{*}(1-s+2 s d)+\alpha\left(1-\beta^{*}(1-s+2 s d)\right)$.

Let $c=1 /(1-s+2 s d), c>1 / 2$,

then the ESS corresponds to

$\alpha /(c-\beta)$ at its maximum value.

Graphically, this corresponds to the tangent between the fitness set and a line crossing the $\beta$ axis at point $c$.

The situation, here, is more complex than in the first case since the following possibilities arise (fig. 2a, 2b, 2c).

1) When $d=1 / 2$, is equivalent to $s=0$ (fig. 2a), selfing does not influence the strategy (as already stated by Charnov, 1982). The result found here is the same as in Charnov et al. (1976).

2) When $d<1 / 2$, there is strong heterosis (fig. $2 b$ ), and this gives $c>1$.

Compared to the case when $s=0, \alpha^{*}$ is increased. This can be explained as follows : instead of wasting resources in the production of ovules which are likely to be selfed and, thus, result in weak individuals, it is better to try to fertilize the female's own ovules. The strong heterosis pays the cost of meiosis. 


\section{TABLE 2}

Fitness of a hermaphrodite of strategy $(\alpha, \beta)$

in a population containing females and hermaphrodites of strategy $\left(\alpha^{*}, \beta^{*}\right)$.

Valeur sélective d'un hermaphrodite de stratégie $(\alpha, \beta)$

dans une population contenant des femelles et des hermaphrodites de stratégie $\left(\alpha^{*}, \beta^{*}\right)$.

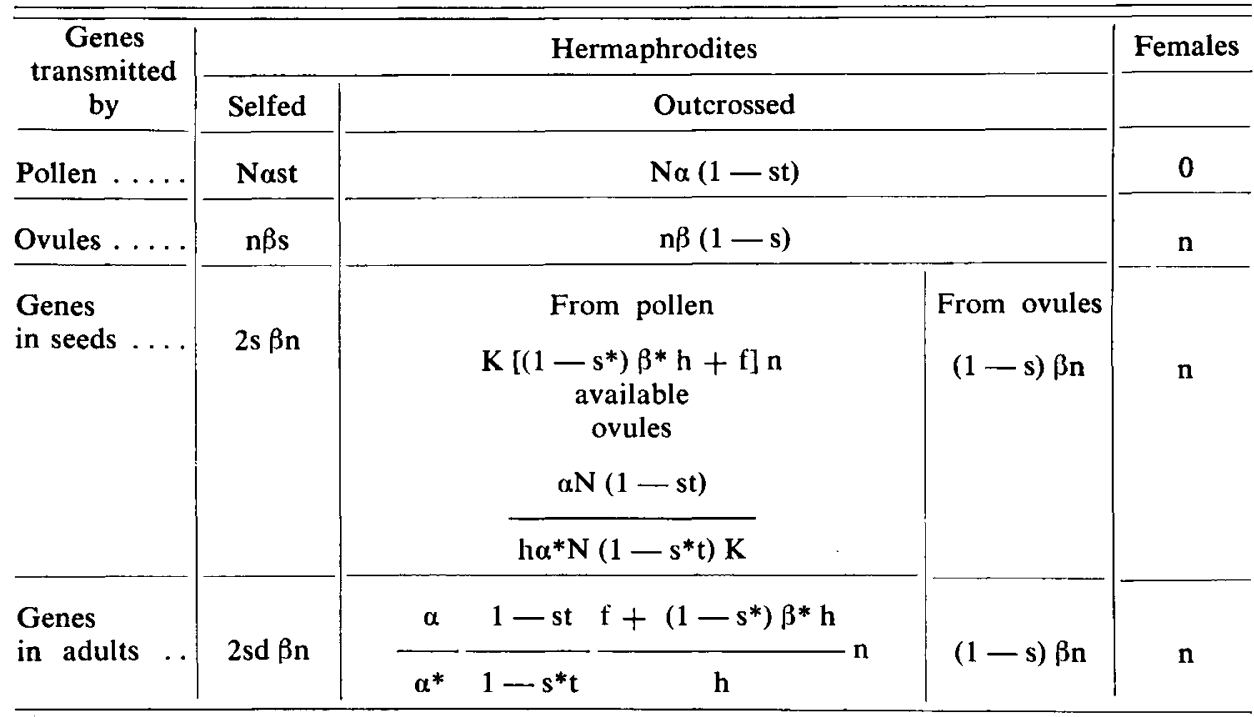

With $\bar{W}=n\left[f+h \beta^{*}\left(1-s^{*}+s^{*} d\right)\right]$

$$
W h=\frac{\beta(1-s+2 s d)}{f+h \beta^{*}\left(1-s^{*}+s^{*} d\right)}+\cdot \frac{\alpha}{\alpha^{*}} \frac{1-s t}{1-s^{* t} t} \frac{f+h \beta^{*}\left(1-s^{* 1}\right.}{h f+h^{2} \beta^{*}\left(1-s^{*}+s^{*} d\right)}
$$

and $\quad W f=\frac{1}{f+h \beta^{*}\left(1-s^{*}+s^{*} d\right)}$

$\mathbf{K}=$ Total number of indviduals.

3) When $d>1 / 2$, there is weak heterosis (fig. 2c), and this gives $c<1$.

Two cases seem to exist here.

- The first case is when there is still a tangent to the fitness set. Compared with the case when $s=0, \beta^{*}$ is then increased. It is interesting to produce ovules and to self them : the cost of meiosis is not paid.

- The second case is when there is no tangent to the fitness set. In this case, there seems to be no stable strategy for the hermaphrodites, since every increase in $\beta$ is selected for and $\alpha$ tends toward the value of 0 . This situation should lead to complete selfing and cleistogamy with a drastic reduction in the pollen production. The reduction of pollen production in relation with cleistogamy has been reported in some species (LORD, 1980). In fact, if this happened, the females would be unable to 
be fertilized and would have a frequency dependent fitness. The model used here is too simple to describe the evolution of the population in this case.

\section{Conclusion}

It is possible to summarize these results as follows.

Compared with the situation without selfing, when selfing occurs, the stable strategy of hermaphrodites is changed in different ways according to the shape of the fitness set and the strength of heterosis.

1) If the fitness set is such that only hermaphrodites occur, the maternal investment is increased.

2) If the fitness set is such that hermaphrodites and females occur together :

- either heterosis is strong and the paternal investment is increased;

- or heterosis is weak and the maternal investment is increased.

In self compatible species, the investment in the male and female functions are then very likely not to be equal. An example of this sort was given by SMITH (1981) on Lodgepole pine. In this species, where only hermaphrodites occur, when they reproduce partly by selfing, the female investment is higher than the male one. This result is in agreement with the results presented here. In gynodioicious species, when the inbreeding depression is strong, which is the case for Thyme, for instance, as shown by PERrot et al. (1982), the effect of selfing could be an important reduction of female production in hermaphrodites (fig. 2).

Received 3 novembrer 1982. Accepted 16 december 1982.

\section{Acknowledgements}

The author wants to thank D. Charlesworth, L. JACKSON, J. MAYNARD-Smith and G. VALDEYRON for helpful comments and discussions.

\section{References}

Charlesworth D., Charlesworth B., 1981. Allocation of ressources to male and female functions in hermaphrodites. Biol. J. Linnean Soc., 15, 57-74.

Charnov E.L., Maynard-Smith J., Bull J.J., 1976. Why be an hermaphrodite? Nature, 263, 125-126.

Charnov E.L., 1982. The theory of sex allocation. Princeton University Press.

LORD E.M., 1980. Intra inflorescence variability in pollen/ovule ratios in Lamium amplexicaule. Amer. J. Bot., 67 (4), 529-533.

Perrot V., Dommee B., Jacquard P., 1982. Etude expérimentale de la concurrence entre individus issus d'autofécondation et d'allofécondation chez le Thym. Acta $E_{\text {col }}$ E Ecol. Plant., 3 (17), 2, 171-184.

SMITH C.C., 1981. The facultative adjustment of sex ratio in lodgepole pine. Amer. ıNat., 118, $297-305$. 